\title{
X-Ray Fluorescence Analysis of XII-XIV Century Italian Gold Coins
}

\author{
Monica Baldassarri, ${ }^{1}$ Gildo de Holanda Cavalcanti, ${ }^{2}$ Marco Ferretti, ${ }^{3}$ \\ Astrik Gorghinian, ${ }^{4}$ Emanuela Grifoni, ${ }^{5}$ Stefano Legnaioli, ${ }^{6}$ Giulia Lorenzetti, ${ }^{6}$ \\ Stefano Pagnotta, ${ }^{6}$ Luciano Marras, ${ }^{5}$ Eleonora Violano, ${ }^{6}$ \\ Marco Lezzerini, ${ }^{7}$ and Vincenzo Palleschi ${ }^{6,8}$ \\ ${ }^{1}$ Civic Museum of Montopoli Val d'Arno, Via Guicciardini 55, 56020 Montopoli V/A, Italy \\ ${ }^{2}$ Institute of Physics, Federal University Fluminense, Avenida Gal. Milton Tavares de Souza, s/n ${ }^{\circ}$ Campus da Praia Vermelha, \\ 24210-346 Niterói, Ri, Brazil \\ ${ }^{3}$ Institute for Technologies Applied to Cultural Heritage, Area della Ricerca Roma 1, Montelibretti, \\ Via Salaria Km. 29.300, CP 10, Monterotondo Street, 00016 Rome, Italy \\ ${ }^{4}$ National Institute of Nuclear Physics, National Laboratories of Frascati (INFN-LNF), Via Enrico Fermi 40, \\ Frascati, 00044 Rome, Italy \\ ${ }^{5}$ Art-Test s.a.s, Via del Martello 14, 56121 Pisa, Italy \\ ${ }^{6}$ Institute of Chemistry of Organometallic Compounds, CNR, Area della Ricerca del CNR di Pisa, Via Galvani 1, 56126 Pisa, Italy \\ ${ }^{7}$ Department of Earth Sciences, University of Pisa, Via Santa Maria 53, 56126 Pisa, Italy \\ ${ }^{8}$ Department of Civilizations and Forms of Knowledge, University of Pisa, Via Galvani 1, 56126 Pisa, Italy
}

Correspondence should be addressed to Vincenzo Palleschi; vincenzo.palleschi@cnr.it

Received 30 April 2014; Revised 1 September 2014; Accepted 11 September 2014; Published 8 October 2014

Academic Editor: Ludovic Slimak

Copyright (C) 2014 Monica Baldassarri et al. This is an open access article distributed under the Creative Commons Attribution License, which permits unrestricted use, distribution, and reproduction in any medium, provided the original work is properly cited.

An extensive analytical study has been performed on a large number of gold coins (Norman-Swabian Augustale and Tari, Grosso of Lucca, Florin of Florence) minted in Italy from the end of XII century to XIV century. The X-ray fluorescence (XRF) technique was used for verifying the composition of the coins. XRF is a nondestructive technique particularly suited for in situ quantitative analysis of gold and minor elements in the precious alloy. The Florins turned out to have a gold content very close to 24 carats (pure gold) although in a couple of cases we observed relatively high concentrations of iron (around 2\%) or lead (around 1\%). The Grosso of Lucca has a similar composition, with a measured gold content around $97 \%$ due to a higher silver percentage (about $2 \%$ ), with respect to the average Florin. The Augustali analyzed showed, on average, a gold content around $89 \%$. The average gold content of the Tari analysed is around $72 \%$, with a relatively large variability. The analysis revealed the use of native gold for the coinage of the Florins, excluding the possibility of recycling gold coming from other sources. On the other hand, the variability observed in the compositions of the Tari and Augustali could suggest the reuse of Islamic and North African gold. The study could shed some light on the sudden diffusion of gold coins in Italy around the first half of XIII century, allowing hypotheses on the provenience of the gold used for a coinage that dominated the economic trades from then on.

\section{Introduction}

The analytical determination of ancient coins' composition is important for gathering information about the historical situation and the commercial exchanges at the place and time of their coinage [1-3]. However, it is also a particularly challenging task that has to take into account the historical, numismatic, and economic value of the object under study.

The analytical methods routinely used for the laboratory analysis of metallic samples in most of the cases cannot be used because of the intrinsic destructivity of most of those techniques $[4,5]$. In fact, even when the importance of the 
analysis would justify the sacrifice of some coin, the results gathered on a very limited number of samples may suffer from the lack of reproducibility associated with the poor statistics.

In recent years, the introduction of cheap, portable $\mathrm{X}$-ray fluorescence (XRF) instrumentation seems to have changed this scenario, providing a viable solution for the nondestructive analysis of scarce or very precious coins but also for the study of a large quantity of samples, eventually hosted in museums or private deposits [6, 7]. Although the intrinsic limitations and drawbacks associated with XRF analysis in numismatics are often underestimated, it is a matter of fact that, in a few years, the introduction of this technique has allowed the gathering of precious information, for instance, on more than 1000 Roman nummi belonging to the Misurata Treasure that were analysed in situ, at the Leptis Magna Museum (Al Khums, Libya), by Romano et al. [8] and, similarly, on hundreds of Roman silver denarii analysed in 2012 by Pardini et al. [9].

The XRF analysis of precious metal coins is particularly interesting because of the relatively less important surface effects affecting the reliability of the results, with respect to copper-based coins [10].

The present paper is devoted to the study of a large gold coin horde (The Tesoretto of Loggia dei Banchi) casually found in Pisa in 1925, during the excavations for the realization of a hotel.

\section{Material and Methods}

The horde was composed of 229 gold coins accumulated probably in the last decade of XIII century $[11,12]$. About onehalf of the coins were coined between 1196 and 1266-1270, while the rest was coined between 1252 and 1290, that is, in between the first years of the kingdom of Frederick II and the end of the ruling of Count Ugolino della Gherardesca.

The measurements on the coins of the Tesoretto dei Banchi were performed at the Museum of S. Matteo in Pisa, where the coins are presently conserved. Of the 229 coins forming the Tesoretto, 26 Florins, 15 Augustali, 1 half Augustale, 36 Tari, and 1 Grosso of Lucca (see Figure 1) were analyzed.

The instrument used was a portable ED-XRF system produced by Amptek Inc. (USA). The measurements were performed at $40 \mathrm{kV} / 15 \mu \mathrm{A}$; the spectra were acquired for 60 seconds.

The quantitative analysis was performed using the PyMCA open source software, realized by the Software Group of the European Synchrotron Radiation Facility (ESRF) [13]. PyMCA is a powerful tool for the processing and the quantitative analysis of XRF spectra. The software performs the analysis using the "fundamental parameters" method, that is, a (in principle) standardless approach which derives the elemental composition of the sample from the basic spectroscopic parameters (fluorescence intensities, absorption coefficients, emission energies, and so forth.) of the elements under study.
The essential requirement for applying the method is the knowledge of the spectrum of the X-ray tube emission and the absolute intensity of the radiation on the sample, which is needed for the normalization of the elements' concentrations. This latter parameter is difficult to determine experimentally; therefore, the fundamental parameters method relies on the use of at least one standard, with a known composition similar to the unknown samples to be analyzed, for the empirical determination of the X-ray intensity on the sample.

In our case, 13 different reference samples ( 6 modern coins of known composition and 7 samples specifically realized by the Institute for Energetics and Interphases of CNR for a previous project, finalized to the development of analytical techniques for nondestructive analysis of precious alloys) were used for improving the trueness of the quantitative results. These samples covered a range of gold concentration between 200/1000 and 999.9/1000 and were used for calibration in the fundamental parameter method, although in principle just one reference sample would have been needed.

However, it has to be noted that the references materials used were only certified for gold, silver, and copper concentrations. The coins here analyzed showed also the presence of $\mathrm{Fe}, \mathrm{Pb}$, and $\mathrm{Pd}$; the quantification of these elements was thus less accurate with respect to $\mathrm{Au}, \mathrm{Cu}$, and $\mathrm{Ag}$ because of the lack of proper (matrix matched) standards. The uncertainty on the absolute determination of the minor elements resulted, in turn, in a slight systematic overestimation on the gold concentration for the coins where the presence of $\mathrm{Fe}, \mathrm{Pb}$, and Pd was not negligible (Augustali and Tari).

In fact, for improving the trueness of the analytical results, the gold content of the coins was determined by difference, that is, $100 \%$ minus the concentrations of the other elements $(\mathrm{Cu}, \mathrm{Ag}, \mathrm{Fe}, \mathrm{Pb}$, and $\mathrm{Pd})$. The composition of each coin was determined as the average of the two measurements performed on the different sides.

\section{Results}

Figure 2 shows the comparison of the compositions of the 26 Florins of the Tesoretto dei Banchi here analyzed. Note in Figures 2-4 the break in the $y$-axis and the different scales before and after the break.

The Florins, as expected, have a gold content very close to 24 carats (pure gold) although in a couple of cases we observe Fe concentrations around 2\% (sample 11) and $\mathrm{Pb}$ concentrations around 1\% (sample 13). However, on average, the gold content of the Florins analyzed is around 99\%, as reported in Table 1

The Grosso of Lucca has a similar composition, with a measured gold content around $97 \%$ due to a higher silver percentage (about 2\%), with respect to the average Florin. However, since only one Grosso was found in the Tesoretto, it is difficult to assess whether this difference is significant or not. On the other hand, the nominal gold content of the Grosso is reported in the mint documents of the times to be 23.75 carats, to be compared to the nearly 24 carats of 


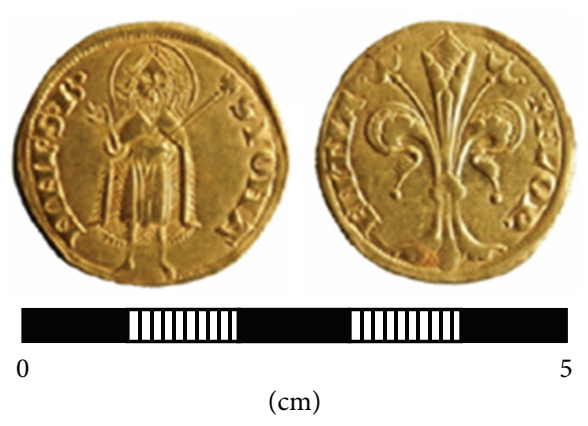

(a)

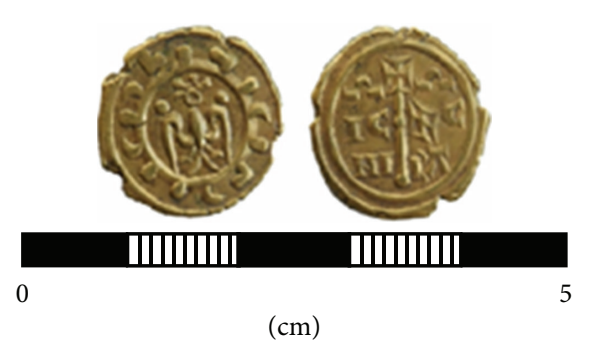

(c)

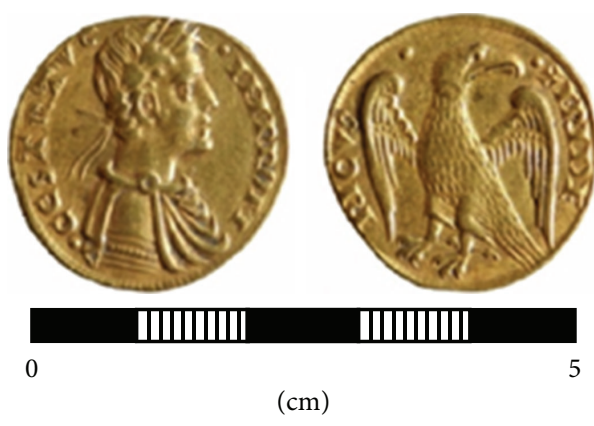

(b)

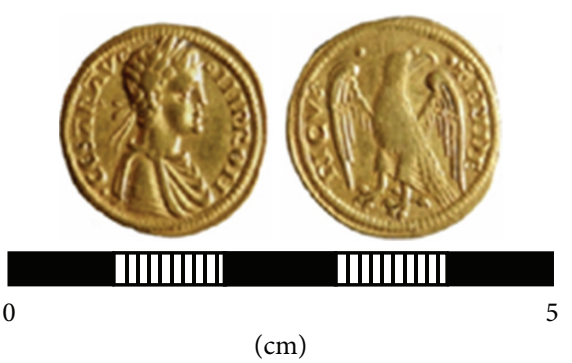

(d)

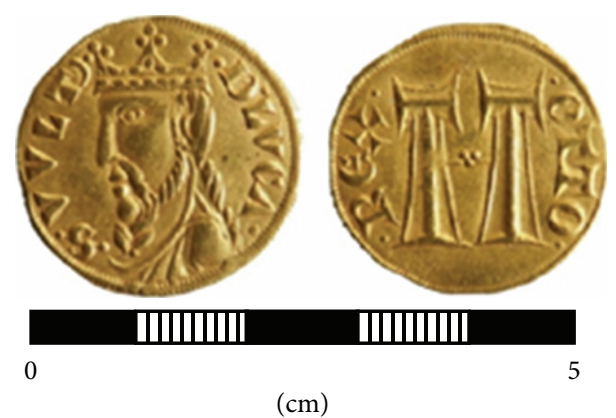

(e)

FIgure 1: The coins analyzed in this work. (a) Florin; (b) Augustale; (c) Tarì; (d) Half Augustale; (e) Grosso of Lucca.

TABLE 1: Average concentrations and mean variations of the Florins analysed.

\begin{tabular}{lc}
\hline Element & Concentration $(w \%)$ \\
\hline $\mathrm{Fe}$ & $0.5 \pm 0.3$ \\
$\mathrm{Cu}$ & $0.06 \pm 0.04$ \\
$\mathrm{Ag}$ & $0.15 \pm 0.09$ \\
$\mathrm{~Pb}$ & $0.31 \pm 0.09$ \\
$\mathrm{Au}$ & $\mathbf{9 8 . 9} \pm \mathbf{0 . 0 4}$ \\
\hline
\end{tabular}

the Florin [14]. The results of the XRF analysis confirm this difference.

The Augustali analyzed showed, on average, a gold content around 89\%, as shown in Figure 3 and in Table 2.

The composition of the half Augustale is very similar to the one of the Augustali analysed (gold content around 89\%) with a similar percentage of copper (1.5\%) and silver (8.4\%).
TABLE 2: Average concentrations and mean variations of the Augustali analysed.

\begin{tabular}{lc}
\hline Element & Concentration $(w \%)$ \\
\hline $\mathrm{Fe}$ & $0.5 \pm 0.1$ \\
$\mathrm{Cu}$ & $\mathbf{1 . 3} \pm \mathbf{0 . 4}$ \\
$\mathrm{Pd}$ & $0.18 \pm 0.05$ \\
$\mathrm{Ag}$ & $\mathbf{1 0} \pm \mathbf{1}$ \\
$\mathrm{Pb}$ & 0.3 \\
$\mathrm{Au}$ & $\mathbf{8 9} \pm \mathbf{1}$ \\
\hline
\end{tabular}

The composition of the Tari, on the other hand, is more variable, as can be observed in Figure 4.

The average gold content of the Tarì analysed is around $72 \%$, ranging from a minimum of $66 \%$ of sample 1 (Tarì of Conrad II and Manfred) to a maximum of $80 \%$ for samples 13 and 23 (Tarì of Frederick II). Sample 7 (Tarì of Henry VI) also shows a relatively high concentration of iron (2\%) 


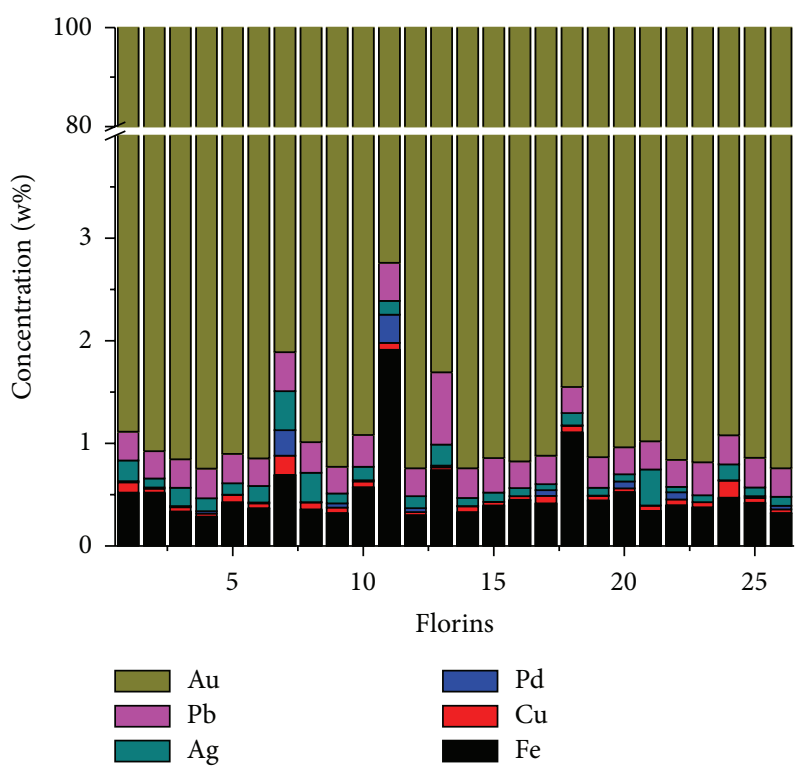

Figure 2: Composition of the 26 Florins from the Tesoretto dei Banchi.

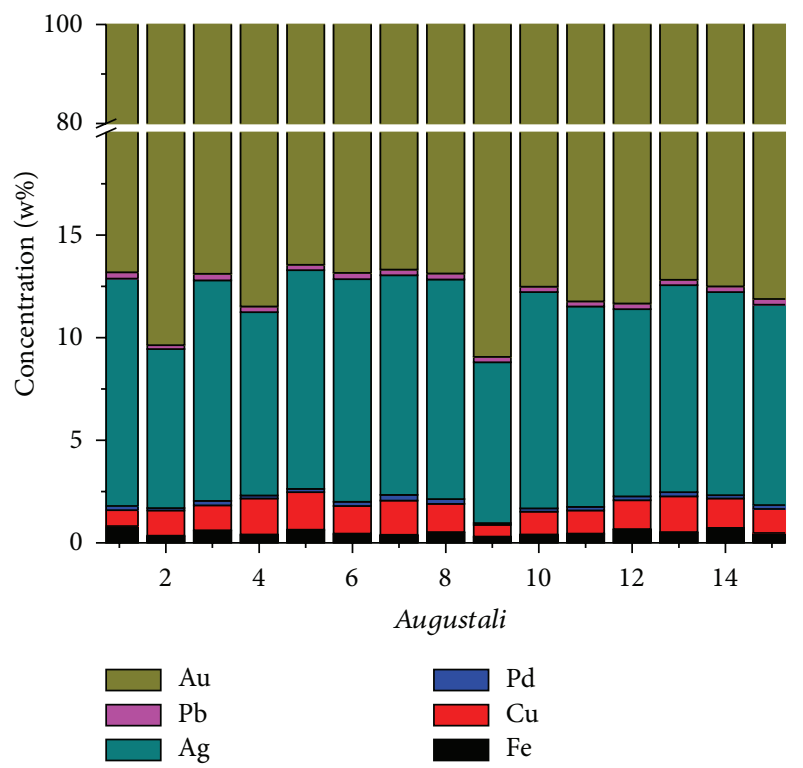

Figure 3: Composition of the 15 Augustali from the Tesoretto dei Banchi.

with respect to the others. The high variability in composition observed in the Tarì confirms the results of Travaini [15]. The average composition of the Tari analysed is reported in Table 3.

\section{Discussion}

The historical interest of the Tesoretto is stimulated by the fact that Pisa would not mint gold coins until the beginning of XIV century; this is generally interpreted as a sign of the decadence of the city after the defeat in the Battle of Meloria

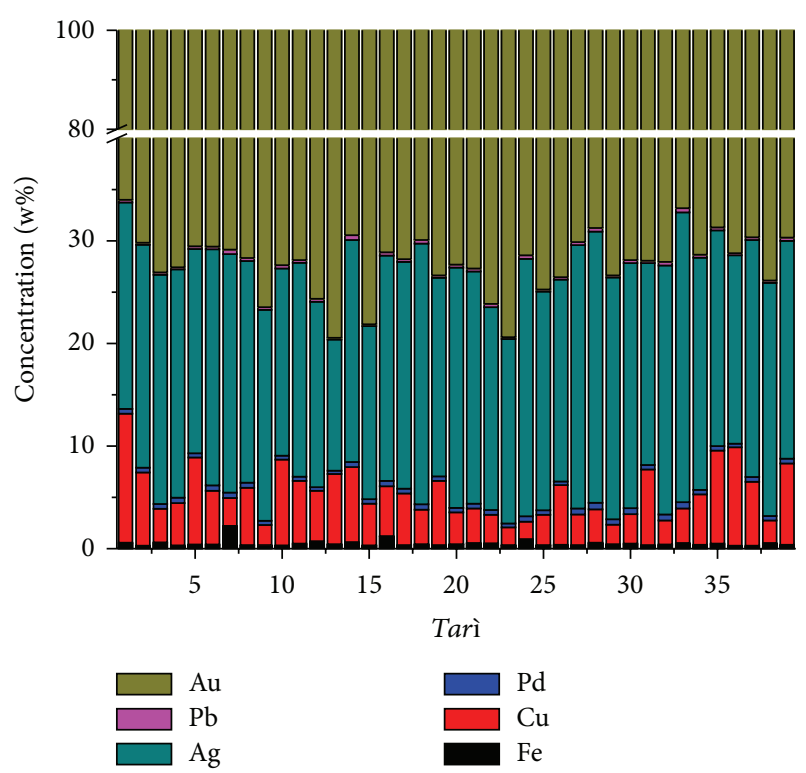

FIgure 4: Composition of the 36 Tari from the Tesoretto dei Banchi.

TABLE 3: Average concentrations and mean variations of the Tari analysed.

\begin{tabular}{lc}
\hline Element & Concentration $(w \%)$ \\
\hline $\mathrm{Fe}$ & $0.5 \pm 0.3$ \\
$\mathrm{Cu}$ & $\mathbf{5} \pm \mathbf{3}$ \\
$\mathrm{Pd}$ & $0.48 \pm 0.08$ \\
$\mathrm{Ag}$ & $\mathbf{2 2} \pm \mathbf{3}$ \\
$\mathrm{Pb}$ & $0.28 \pm 0.07$ \\
$\mathrm{Au}$ & $\mathbf{7 2} \pm \mathbf{3}$ \\
\hline
\end{tabular}

against Genoa (1284), although it is also possible that the gold coins of the Empire, mainly Tari and Augustali, were used in Pisa instead of its own coinage. The abundance of these coins in the Tesoretto, in any case, indicates the existence of important political and commercial relationships between Pisa and the kingdom of Frederick II in southern Italy. Also noteworthy is the presence of an extremely rare coin, the Grosso (Groat) of Lucca, whose date of first coinage is still debated (1246, six years before the introduction of Florins and Genovini, according to Lenzi [14], or 1256, four years after, according to Blomquist [16]).

The reintroduction of gold coinage in the western Europe, in fact, represents a kind of mystery per se. In central and western Europe, the coinage remained essentially monometallic (based on silver) for about five centuries, after the monetary reformation of Charles the Great in 798 introducing the new silver denarius that will become the standard currency in western and central Europe.

In the years between 1250 and 1256, three important mints in central/northern Italy (Florence, Lucca, and Genova) started to produce gold coins after about 450 years of substantially monometallic coinage based on silver.

On the other hand, the use of gold coins practically never stopped in southern Italy and the Islamic Sicily. The 
influence of this long-standing technological experience on cities such as Genoa and Florence, which introduced their golden Genovini and Florins almost simultaneously in 1252, has been recently discussed by Travaini [17]. As a matter of fact, the introduction of Genovini and Florins was anticipated by the minting of the Augustale by Frederick II, in the Norman-Swabian kingdom of southern Italy around 1231. The Augustale was the first gold coin in southern Italy produced with typologies and standard different from the Islamic gold coinage of the times.

However, the origin of the gold used by the Genoa and Florence mints is yet unclear. It has been suggested that the increase of the commercial exchanges with the East would have provided a steady flux of gold, producing in turn a devaluation with respect to silver and favouring the reintroduction of a stable gold coinage in the commercial cities of the time [18]. The sack of Constantinople of 1204, during the fourth crusade, also brought to the West large quantities of gold, contributing to the decrease of the value of this metal. In fact, also Venice, after Genoa and Florence, would later on mint a gold coin, the Ducato, identical in weight and gold title to the Genovini and Florins, in 1284. Florins and Ducati would define the gold standard in Europe up to the XIII century and in Italy up to the end of XV century.

The compositional analysis of the number of gold coins belonging to that period was thus intended as a way of comparing the standards of the new gold coins issued in central Italy (Florence and Lucca) with the gold coins already circulating for at least 20 years in southern Italy. Our analysis, the first performed on statistically significant early Florins, in situ and with completely nondestructive methods, allowed to determine that the Florin was issued since its very first introduction with a high purity standard, unprecedented in the Norman-Swabian coinage. This finding supports the use of native gold for the coinage of the Florins, excluding the possibility of recycling of gold coming from other sources. This is important because it implies both the existence of a stable supply of precious metal supporting the new coinage and the precise intent of Florence to issue a coin that would soon dominate the market because of its high purity standard. On the other hand, the high variability observed in the compositions of the Tarì and, to a lesser extent, in the Augustali, could suggest the reuse of Islamic and North African gold, as also proposed by Gondonneau and Guerra [19], on the basis of complex laboratory instrumentation $(12 \mathrm{MeV}$ proton activation analysis) [20] and, for some specimens, destructive analysis such as LA-ICP-MS [21].

\section{Conclusion}

The possibility of testing, in situ and nondestructively, a large quantity of samples for both the major elements and for the minority elements in the precious alloy supports the use of native gold for the coinage of the Florins, excluding the possibility of recycling of gold coming from other sources. On the other hand, the variability observed in the compositions of the Tari and Augustali could suggest the reuse of Islamic and North African gold. These findings would possibly help the scholars in formulating hypotheses on the provenience of the raw material used for such extensive coinage, which would dominate the commercial exchanges and the European economy for more than two and a half centuries.

\section{Conflict of Interests}

The authors declare that there is no conflict of interests regarding the publication of this paper.

\section{References}

[1] E. L. Szonntagh, "Sampling method for representative elemental analysis of non-homogeneous coins," Mikrochimica Acta, vol. 75, no. 3-4, pp. 191-205, 1981.

[2] C. Vlachou, J. G. McDonnell, and R. C. Janaway, "Experimental investigation of silvering in late roman coinage," Materials Research Society Symposia Proceedings, vol. 712, pp. 461-470, 2002.

[3] B. E. Woytek, K. Uhlir, M. Alram, M. Schreiner, and M. Griesser, "The denarius under trajan: new metallurgical analyses," Numismatic Chronicle, vol. 167, pp. 147-163, 2007.

[4] G. Sarah, B. Gratuze, and J.-N. Barrandon, "Application of laser ablation inductively coupled plasma mass spectrometry (LAICP-MS) for the investigation of ancient silver coins," Journal of Analytical Atomic Spectrometry, vol. 22, no. 9, pp. 1163-1167, 2007.

[5] L. Torrisi, F. Caridi, L. Giuffrida et al., "LAMQS analysis applied to ancient Egyptian bronze coins," Nuclear Instruments and Methods in Physics Research Section B: Beam Interactions with Materials and Atoms, vol. 268, no. 10, pp. 1657-1664, 2010.

[6] M. F. Guerra, "An overview on the ancient goldsmith's skill and the circulation of gold in the past: the role of $x$-ray based techniques," X-Ray Spectrometry, vol. 37, no. 4, pp. 317-327, 2008.

[7] V. Kantarelou, F. J. Ager, D. Eugenidou et al., "X-ray Fluorescence analytical criteria to assess the fineness of ancient silver coins: application on Ptolemaic coinage," Spectrochimica ActaPart B Atomic Spectroscopy, vol. 66, no. 9-10, pp. 681-690, 2011.

[8] F. P. Romano, S. Garraffo, L. Pappalardo, and F. Rizzo, "In situ investigation of the surface silvering of late Roman coins by combined use of high energy broad-beam and low energy micro-beam X-ray fluorescence techniques," Spectrochimica Acta-Part B Atomic Spectroscopy, vol. 73, pp. 13-19, 2012.

[9] L. Pardini, A. El Hassan, M. Ferretti et al., "X-ray fluorescence and laser-induced breakdown spectroscopy analysis of Roman silver denarii," Spectrochimica Acta. Part B Atomic Spectroscopy, vol. 74-75, pp. 156-161, 2012.

[10] A. Denker, W. Bohne, J. Opitz-Coutureau, J. Rauschenberg, J. Röhrich, and E. Strub, "Influence of corrosion layers on quantitative analysis," Nuclear Instruments and Methods in Physics Research Section B: Beam Interactions with Materials and Atoms, vol. 239, no. 1-2, pp. 65-70, 2005.

[11] L. Lenzi and E. Cristiani, Il ripostiglio di monete auree scoperto in Pisa sotto le logge dei Banchi, Pisa, 1978, (Italian).

[12] M. Baldassarri and M. Burresi, Il Tesoretto di Banchi un Ripostiglio Pisano di Monete Auree Medievali, Bandecchi \& Vivaldi, Pontedera, Italy, 2000, (Italian). 
[13] V. A. Solé, E. Papillon, M. Cotte, P. Walter, and J. Susini, "A multiplatform code for the analysis of energy-dispersive Xray fluorescence spectra," Spectrochimica Acta Part B: Atomic Spectroscopy, vol. 62, no. 1, pp. 63-68, 2007.

[14] L. Lenzi, "Il Grosso d'oro di Lucca: 1246?" Memorie dell'Accademia Italiana di Studi Filatelici e Numismatici, vol. 6, p. 73, 1995.

[15] L. Travaini, "The fineness of Sicilian taris and of those of Amalfi and Salerno (11th to 13th centuries)," in Metallurgy in Numismatics, W. A. Oddy and M. R. Cowell, Eds., vol. 4, Special publication 30, pp. 504-517, Royal Numismatic Society, London, UK, 1998.

[16] T. W. Blomquist, "The second issuance of a Tuscan gold coin: the gold groat of Lucca, 1256," Journal of Medieval History, vol. 13, no. 4, pp. 317-325, 1987.

[17] L. Travaini, Monete e storia nell'Italia medievale, Libreria dello Stato, Istituto poligrafico e Zecca dello Stato, Rome, Italy, 2007, (Italian).

[18] M. Cattini, "Argento, oro e monete in Europa dal IX al XV secolo," in lo Scudo d'Oro. Moneta e Potere da Augusto a Carlo $V$, Soprintendenza Archeologica di Roma, Rome, Italy, 1996, (Italian).

[19] A. Gondonneau and M. F. Guerra, “The circulation of precious metals in the Arab empire: the case of the near and the Middle East," Archaeometry, vol. 44, no. 4, pp. 573-599, 2002.

[20] J.-N. Barrandon, J.-L. Debrun, and M. Hours, Application des Réactions Nucléaires Induites par des Protons de Moyenne Énergie à la Caractérisation des Ors Anciens, Accademia Nazionale dei Lincei, Rome, Italy, 1976, (French).

[21] M. F. Guerra, C.-O. Sarthre, A. Gondonneau, and J.-N. Barrandon, "Precious metals and provenance enquiries using LA-ICPMS," Journal of Archaeological Science, vol. 26, no. 8, pp. 11011110, 1999. 

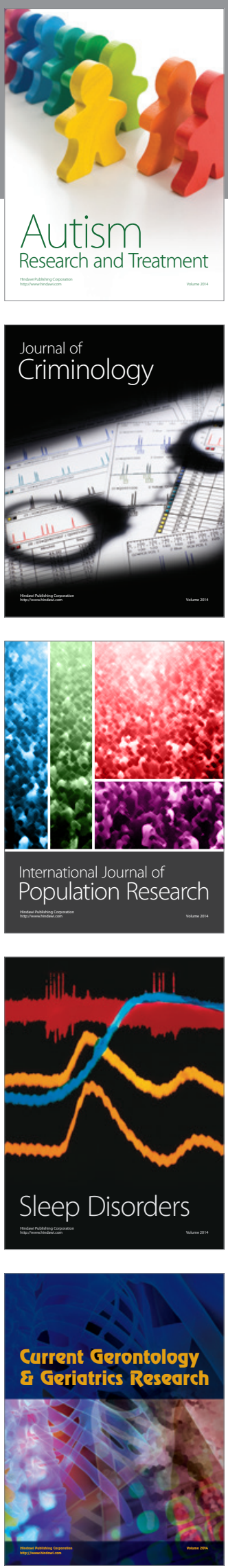
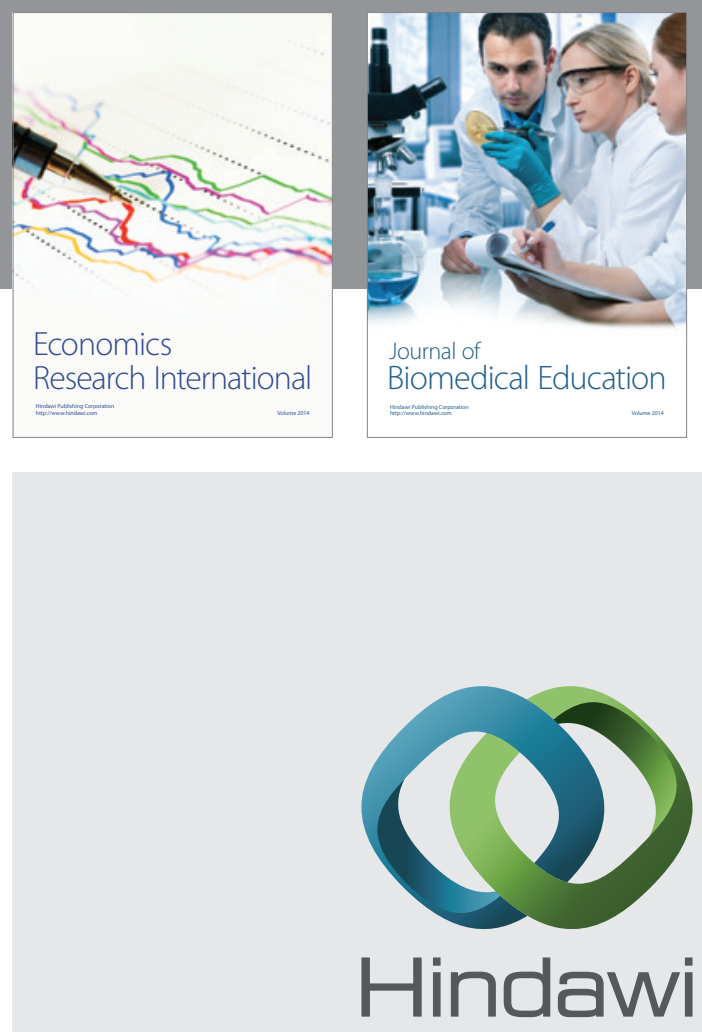

Submit your manuscripts at

http://www.hindawi.com
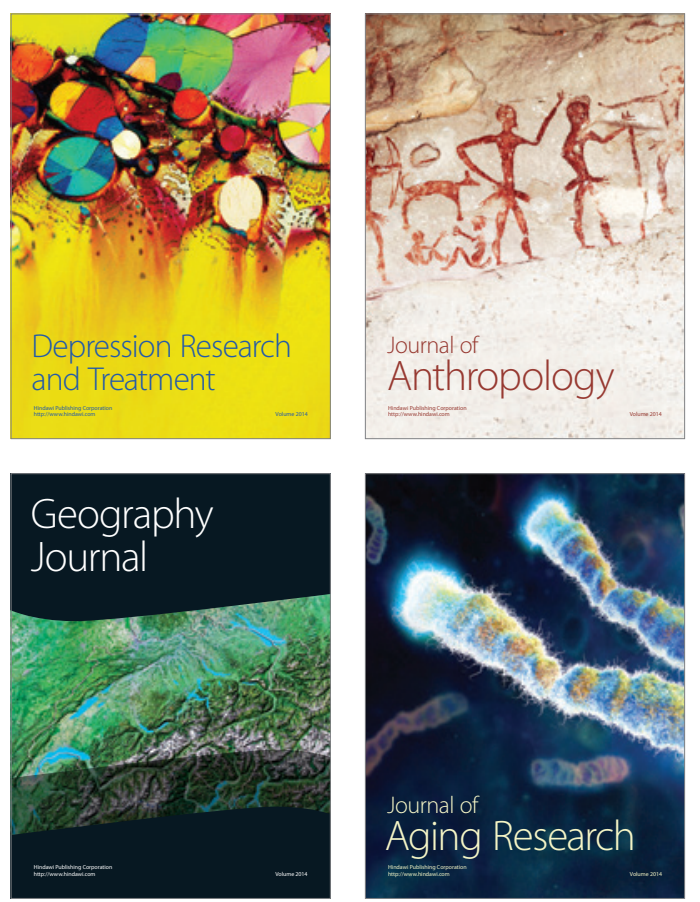
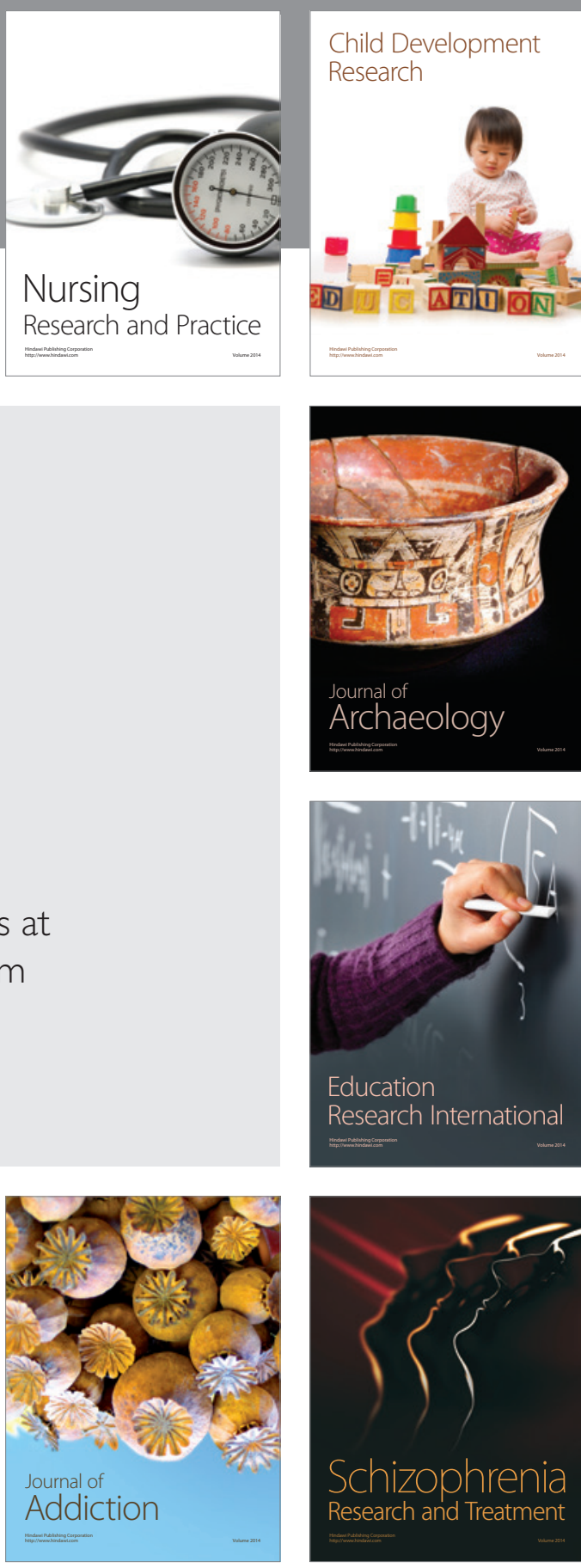

(D)
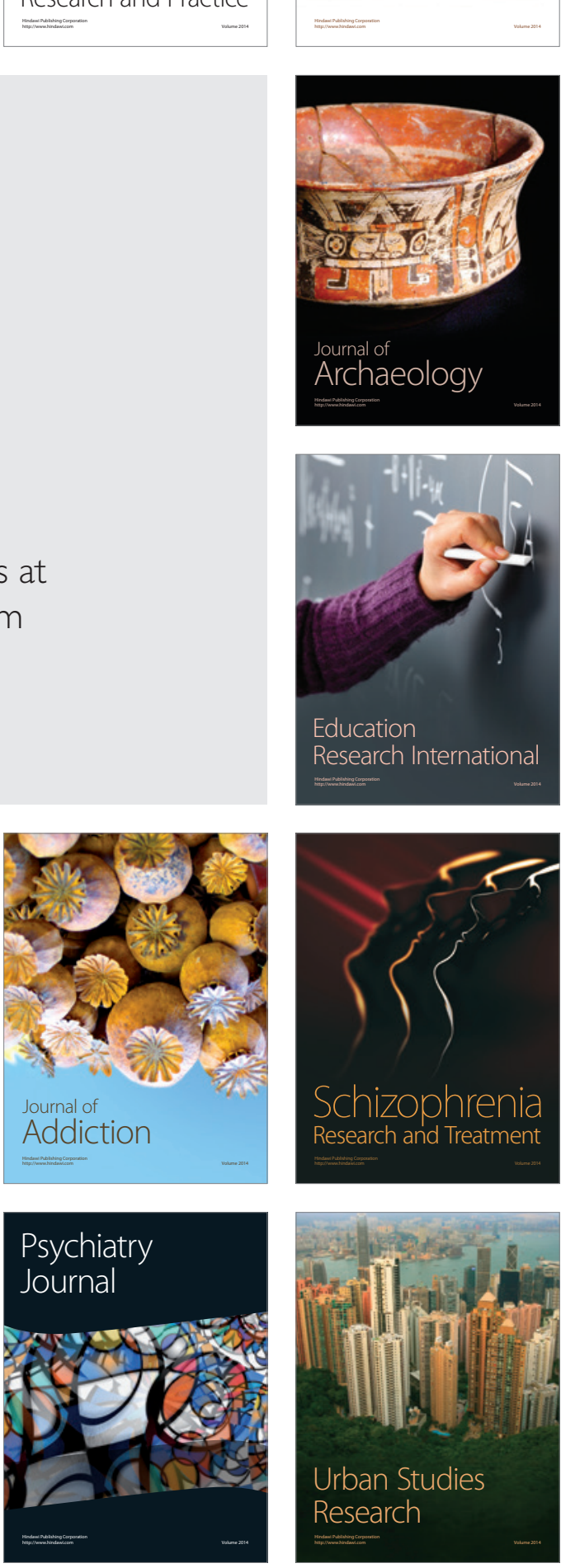